\title{
The Dynamics of Muslims' Perspectives on the Ceremony of Nawu Sendang Saliran in Yogyakarta
}

\author{
Sulfia Lilin Nurindah Sari \\ Universitas Nahdlatul Ulama (UNU) Kalimantan Timur, Samarinda \\ silvia.candle@gmail.com
}

\begin{abstract}
Abstrak
Artikel ini menyajikan studi kasus tentang konflik yang terjadi karena perbedaan perspektif di kalangan umat Islam mengenai acara Nawu Sendang Saliran. Sendang Saliran merupakan kolam bersejarah, dan tujuan dari upacara ini adalah untuk membersihkan kolam tersebut dengan melakukan rangkaian acara budaya. Acara yang hanya bertujuan mempertahankan tradisi untuk membersihkan kolam dan mempromosikan tradisi itu sendiri dan untuk menarik wisatawan, telah menimbulkan kontroversi di kalangan umat Islam dan menimbulkan konflik antara abdi dalem sebagai pelaksana acara dan Muhammadiyah, salah satu organisasi Islam yang mencoba untuk menentangnya. Muhammadiyah menentang acara tersebut karena mereka takut acara semacam ini akan menyebabkan bidah dalam Islam. Untuk mengatasi konflik, para pelaksana acara dan Muhammadiyah mengatur mediasi. Artikel ini menemukan bahwa perbedaan dalam cara-cara Muslim memahami budaya dan peran agama dalam budaya menawarkan penjelasan tentang sikap Muhammadiyah yang masih menentang dilaksanakannya acara Nawu Sendang Saliran.
\end{abstract}

Kata Kunci: Nawu Sendang Saliran, Upacara Keagamaan, Agama, Budaya, Konflik, Mediasi. 


\section{Introduction}

The article interprets the relation between religion and local culture in Indonesia, especially in Java. There are many scholars who have conducted research about the relationship between religion and local culture, both in terms of tension and harmony, including Clifford Geertz (1960), Mark Woodward (2011), Robert W. Hefner (2000), Andrew Betty (1999), and so on. Their explanation about Islam Java is very complex. Some of them discuss about the acculturation of Islam and local culture in Java.

Therefore, this article presents a case study about a misunderstanding occurred because of differing perspectives among Muslims regarding the ceremony of Nawu Sendang Saliran. Sendang Saliran is a historic place, and the purpose of the ceremony is to clean up the place by performing kind of rituals. The ceremony not only maintains the tradition to clean up the place but it is also a tool to promote the tradition itself and to attract tourists. But unwittingly, the ceremony has caused controversy among Muslims. Ulama have opposed the ceremony because they are afraid this kind of ceremony will lead to heresy in Islam. This paper examines the Ulama reasons for why they are still anxious about the ceremony although they and the performers of the ceremony have reached an agreement about how the ceremony can be carried out in an acceptable way. The paper argues that differences in the ways that Muslims understand culture and the role of religion in culture offer an explanation for the Ulama continued opposition to the performance of Nawu Sendang Saliran.

The object of this article is the ceremony of Namu Sendang Saliran. Sendang Saliran is a pool or bathing place for the royal family during the Mataram kingdom period (1587-1613). Whereas, the ceremony of Nawn Sendang Saliran is a ceremony to clean up or to drain the water from the pool. The location of Sendang Saliran itself is in Jagalan village, Banguntapan district, Bantul regency. The area of Sendang Saliran is one complex with the tombs of the kings of Mataram and Masjid Agung (mosque) in kotagede, Jogjakarta. There are two sendang in that place, sendang kakung and sendang putri. Sendang kakung is for men, whereas sendang putri is for women. 
Besides discussing about the ceremony, my focus is also the conflict that occur because of the changing of the ceremony of Nawn Sendang Saliran. The conflict occurs between abdi dalem as the organizers of the ceremony and Muhammadiyah, one of Islamic organizations in that village who try to oppose the ceremony. Muhammadiyah is one of the largest Islamic organization that founded in 1912 by KH. Ahmad Dahlan in Yogyakarta. ${ }^{1}$ Muhammadiyah itself is an organization that known for their religious purification. Therefore, in the ceremony of Nawn Sendang Saliran, one of Muhammadiyah affiliation in Kota Gede tried to oppose the ceremony because of their fears that the ceremony will cause to heresy.

Clearly, Muhammadiyah organization that involve in the conflictive situation with abdi dalem is not all the members of Muhammadiyah organization or Muhammadiyah people. It is caused there is no official statement or fatwa from central Muhammadiyah office that the ceremony of Nawn Sendang Saliran is heresy. Muhammadiyah that involve in the conflictive situation is the member of local Muhammadiyah office in Kota Gede.

In fact, not all Muhammadiyah people have the same thoughts about Islam and refuse local culture. there are many members of Muhammadiyah who do not oppose the acculturation of local culture with Islam, or against local culture. Biyanto explains that now Muhammadiyah try to open up to the local culture and make culture as a tool to proselytize of Islamic doctrine. ${ }^{2}$ From Biyanto's statement, we can take the conclusion that actually not all Muhammadiyah member oppose the existence of local culture. To help us discuss the conflict in the ceremony of Nawu Sendang Saliran, later we call abdi dalem as the performers, and Muhammadiyah as the disputants.

\footnotetext{
${ }^{1}$ Beck, Herman, Islamic Purity at Odds with Javanese Identity: The Muhammadiyah and the Celebration of the Gerebeg Maulud Ritual in Yogyakarta. Ed. Pluralism and Identity by jan Platvoet and Karen Van Der Toorn (Leiden, New York, Koln: E. J. Brill, 1995), 261.

2 Biyanto, "Muhammadiyah dan Problema Hubungan Agama-Budaya", dalam ISLAMICA, Vol. 5, No. 1, September 2010, 89.
}

116 | Sulfia Lilin Nurindah Sari - The Dynamics of Muslims' Perspectives on the Ceremony 


\section{The Purpose of Nawu Sendang Saliran Ceremony}

Sendang Saliran is a pool or bathing place for the royal family during the Mataram kingdom period (1587-1613). The words sendang and saliran are from Javanese language, which is sendang meant the pool, and saliran is from the basic word seliro which meant pretension. Historically, this place is named saliran because it was the desire of Panembahan Senapati, the first king and the founder of the Mataram Sultanate to make a pool and it was made by the king himself not by the soldiers. ${ }^{3}$ Whereas, the ceremony of Nawn Sendang Saliran is a ceremony conducted to clean up the dirty pool after one year has not been cleaned. The word Nawn is also from Javanese language, which means drain or clean up. In this case, Nawn means drain the water from the pool. So, the ceremony of Nawn Sendang Saliran is a ceremony performed to drain the water from the pool, and to clean up the pool from the moss and other mucks.

The ceremony of Nawu Sendang Saliran is operated by abdi dalem (royal servant of Surakarta sultanate and Jogjakarta sultanate) who taking care of Sendang Saliran. In the beginning, the ceremony of Nawu Sendang Saliran was only performed with simple ways. Abdi dalem only used simur (water dipper) to clean up and drain the water from the sendang. But over the time, the ceremony has changed practically. The ceremony that was originally only performed in simple ways and private, turned become a ceremony performed royally and become public ceremony. Therefore, the ceremony that was performed once a year during the month of Mawlid ${ }^{4}$ or Rabiul awal in Islamic calendar, performed on April every year.

The changing of the ceremony of Nawn Sendang Saliran was initiated by the village headman. At the first time, he had a desire to hold a cultural event to introduce local culture in the society and also to promote their village as a tourism village. Starting from these desires, then the ceremony of Nawn Sendang Saliran was held for the first time in 2009, after consulted it with abdi dalem, as the keeper of the place.

\footnotetext{
${ }^{3}$ Slamet, Interview, 16 February 2015.

${ }^{4}$ The word mawlid is from Arabic language, which means birthday. In this case, mawlid is the event to celebrate Prophet Muhammad Saw's birthday. In Indonesia, Muslims usually celebrate Muhammad's birthday and consider it as a special day.
} 
Because of it, many people come to see the ceremony every year. Indirectly, the ceremony is not only as a ceremony to maintain the tradition but also as a tool to promote their village as a historical village and also to attract the tourists.

As usual in a cultural event or ceremony, people do not just celebrate it without a reason. There must be a reason and purpose behind those ceremonies. It is also happened in the ceremony of Nawn Sendang Saliran. The purpose of this ceremony is initially to keep or maintain the local tradition to clean up the Sendang Saliran and drain the water from it after one year was never cleaned. But with the passage of time, the purpose of the ceremony is not only to clean up the sendang and maintain their local tradition, but also to promote their village as city of culture to the tourists. The existence of the ceremony expected to be able to introduce the tradition of Nawn sendang in the world and became one of tourism sites. In addition, gunungan that is organized from kind of traditional foods such as kepo and etc, able to help the society to introduce their traditional foods. They hope it will become the way for them to offer their foods and sell it to the tourists who come to participate or see the ceremony of Nawu Sendang Saliran.

In the tourism aspect, is not just people around the village that are expected to enjoy kind of agendas in the ceremony, but also people from other city as well as people from abroad who visit Indonesia for holiday or any kind of reasons. This case is similar with the case in Lorentzen's article about Mayan Chiapas society. He explained about the Indian society which become the object of tourism because considered as local society. According to Lorentzen, because of their locality, the impact of tourism in the economic aspects is significant for Mayan Chiapas society. ${ }^{5}$ Therefore, in the ceremony of Nawu Sendang Saliran also expected that the society will get the benefit in economical aspect such as in Chiapas society.

\footnotetext{
${ }^{5}$ Lois Ann Lorentzen, "Who is an Indian?: Religion, Globalization and Chiapas", in Hopkins, et al. (eds.), Religions/ Globalization: Theories and Cases (Duke, 2001), 86-87.
}

118 | Sulfia Lilin Nurindah Sari - The Dynamics of Muslims' Perspectives on the Ceremony 


\section{The Conflict in the Ceremony of Nawu Sendang Saliran}

From the explanation above, we can only see the positive impacts of the ceremony. But because of the changing of the ceremony, there was also negative impact for the organizers because of the difference point of view about the cultural performances between abdi dalem as the organizers of the ceremony and Muhammadiyah who try to oppose the ceremony. Those different point of view cause the tension between them. Fortunately, the problem does not trigger violence and disunion in the society. However, the problem could be more rupture and lead violence if there is no proper handling.

There is a question, how could this misunderstanding happen? The misunderstanding began when the ceremony of Nawu Sendang Saliran are routinely conducted every year by the performers to attract tourists. It is happened when the ceremony is performed publicly. Because of the changing of the ceremony, cause much speculation among the Ulama or we call is as the disputants.

The disputants esteemed the ceremony of Nawu Sendang Saliran as kind of heresy or would lead to heresy. Therefore, the disputants tried to oppose it. The reason why they think the ceremony is kind of heresy because they have different understanding about culture. According to the disputants, the ceremony that is conducted by the performers is not fulfill the cultural categorization in Islam. ${ }^{6}$

1. Mediation to solve the problem

Respond to the case of the ceremony of Nawn Sendang Saliran, both abdi dalem as the performers and Muhammadiyah as the disputants try to solve their misunderstanding by conducting mediation. The purpose of the mediation in this case is to explain their understanding about the ceremony so that it can be performed in acceptable ways. It is because each party have a desire to solve the problem amicably without any physical strength. Both sides tried to give opportunity to the other party to explain their concerns in the ceremony of Nawu Sendang Saliran.

\footnotetext{
${ }^{6}$ Suharianto, Interview, 2 March 2015.
} 
In the mediation, there is a process for both parties to describe their opinions or arguments. Each party has the same right to express their opinion without interruption from other party. Stitt mentions this process as storytelling. ${ }^{7}$ Such as mediation in general, the mediator attends to facilitate both parties to present their arguments and also help them to find the best solution so that the ceremony of Nawu Sendang Saliran can still be carried out without causing suspicions from the disputants.

From the disputants, they express their arguments why they do not agree with the arrangement of the ceremony, and also the reason why they keep their suspicious and distrustful to the performers. Whereas, the performers of the ceremony try to deny the disputant's suspicions. They give clarification about the purpose and the arrangements of the ceremony. In addition, the performers also deny that the ceremony is kind of bid'ah or heresy as accused by the disputants.

To help us comprehend the different perspectives from both parties about the ceremony of Nawn Sendang Saliran, we can see the table below.

Table 1.

The disputants and The Performers' perspective in the ceremony of Nawu Sendang Saliran.

\begin{tabular}{|c|l|l|}
\hline No. & \multicolumn{1}{|c|}{ The Disputants } & \multicolumn{1}{c|}{ The Performers } \\
\hline 1 & $\begin{array}{l}\text { There is no clarity about the historical } \\
\text { background of the ceremony }\end{array}$ & $\begin{array}{l}\text { The ceremony has already performed } \\
\text { by their ancestors }\end{array}$ \\
\hline 2 & Gunungan: wasting of foods & $\begin{array}{l}\text { Gunungan: the way they perform food } \\
\text { traditionally }\end{array}$ \\
\hline 3 & $\begin{array}{l}\text { Arak-arakan (pageantry): glorifying } \\
\text { the siwur (watter dipper). }\end{array}$ & $\begin{array}{l}\text { Arak-arakan: symbolic of the } \\
\text { ceremony }\end{array}$ \\
\hline 4 & $\begin{array}{l}\text { Ruwatan (exorsism) in wayang } \\
\text { (puppet) performance }\end{array}$ & $\begin{array}{l}\text { There is no ruwatan in puppet } \\
\text { performance. }\end{array}$ \\
\hline
\end{tabular}

\footnotetext{
7 Allan J. Stitt, Mediation: A Practical Guide (London: Cavendish Publishing Limited, 2004), 69.
}

120 Sulfia Lilin Nurindah Sari - The Dynamics of Muslims' Perspectives on the Ceremony 
From the table above, the performers of the ceremony tried to convince the disputants that the ceremony of Nawn Sendang Saliran has nothing with kind of heresy. The performers clearly clarify that they perform that ceremony just as a tool to promote their village as traditionalist village and also as the object of tourism.

After listening the performers' opinion about the purpose of the ceremony that they performed, the disputants made some regulations so that the ceremony can be carried out in an acceptable way. Those regulations are; no gunungan, arak-arakan, and also ruwatan. But not all of those regulations are agreed by the performers, such as arak-arakan and gunungan. It is because gunungan and arak-arakan are the center of the ceremony and as symbolization. Accept ruwatan, the performers deny that they conduct ruwatan. Therefore, the performers agree for not doing ruwatan because it is not part of the ceremony.

If seen from the agreements that made, we can see the agreements clearly from the table below:

Table 2.

The disputants and the Performers Agreements

\begin{tabular}{|c|c|c|}
\hline No. & The Disputants & The Performers \\
\hline 1 & No gunungan & Yes gunungan \\
\hline 2 & No arak-arakan & Yes arak-arakan \\
\hline 3 & No ruwatan & No ruwatan \\
\hline
\end{tabular}

In the end of mediation, both the disputants and the performers of the ceremony have reached an agreement about how the ceremony can be carried out in an acceptable way. Although the performers will still keep the ceremony with kind of arrangements in the future, but they still try to convince the disputants that they will perform the ceremony without giving spiritual meaning which can lead to the kind of heresy in Islamic religion. The performers just need to decompress the ritual that considered as heresy such as ruwatan in puppet performance.

In addition to the agreement that mentioned above, there is still one more deal agreed by both parties. The disputants consider that addressing the ceremony as a custom is not appropriate because basically the ceremony was not a custom ceremony that is carried out from generation to generation. Therefore, performers agree with the 
disputant's opinion not to call it as cultural ceremony. According to the mediator, "So far there is no heresy and polytheism, the ceremony is fine to be performed."

\section{The Failure of Mediation}

The success of mediation does not necessarily guarantee the completion of the overall problem. Although they organize mediation and achieve some agreements, but it could not eliminate the suspicions and the anxious of the other party about the ceremony. For example, from the disputants, they still insist that the ceremony of Nawn Sendang Saliran cannot be accepted. By doing mediation, conflict is not always settled. Stitt, use Gillie's analysis that the percentage of successful mediation is approximately $70-80 \%$, not fully success. ${ }^{9}$

When we said the mediation is unsuccessful, then it is common to raise some questions. Why the mediation in unsuccessful? What is the cause of the failure? And what is the proof that the mediation is unsuccessful? The few things that become evidences and also the reason of the failure of mediation are, the consistency of the performers in the ceremony, prejudice and blaming each other.

Although there are some agreements that is agreed by both parties, but it does not guarantee the success of the mediation. One of the proofs that the mediation is not success is the arrangements of the ceremony that is problematized by the disputants, still implemented by the performers. Those arrangements are; gunungan gede, arak-arakan, and also wayangan. The performers still implement those arrangements because gunungan, arak-arakan and wayangan are the center and symbolization of the ceremony.

In my analysis, there are two agreements that both the disputants and the performers agreed. those are implementation of ruwatan and calling the ceremony as cultural ceremony. But, those agreements could not be categorized as agreement because those are not part of the ceremony. In the ritual of ruwatan, the performers also deny that they

\footnotetext{
${ }^{8}$ Kharis Zubair, Interview, 27 February 2015.

${ }^{9}$ Stitt, Mediation, 7-8.
}

122 | Sulfia Lilin Nurindah Sari - The Dynamics of Muslims' Perspectives on the Ceremony 
conduct it. So, for the prohibition to perform ruwatan does not affect the ceremony because in fact, they never conduct it. Therefore, the performers agree for not doing the ritual of ruwatan because it is not part of the ceremony.

Meanwhile, the prohibition to call the ceremony as cultural ceremony can little bit be regarded as an agreement because in the beginning, the performers call it as a cultural ceremony. But, if seen the discussion in previous chapter about the disputants and the performers' arguments about the historical background of the ceremony, we also cannot say that the agreement is success. The reason for the failure of the agreement is their different opinion about the historical background of the ceremony. According to the disputants, it cannot be called as a culture because it had never been done by the society and their ancestors. There is no historical background in this ceremony. whereas, for performers, this ceremony has clear history. Although before they perform it without any kind of event such as gunungan gede and arakarakan, but they clean up the Sendang Saliran routinely in mawlid month. The activity to clean it up in mawlid month is the habit from their ancestors who also abdi dalem of mataram sultanate, now Yogyakarta and Surakarta sultanate.

Although, in fact the performers agree not to call it as cultural ceremony, they and the society still consider it as cultural ceremony. It can be seen in the arrangements of the ceremony performed by them. The performances that they implement in general are part of Javanese culture, such as ambengan gede, arak-arakan, and wayangan. Although the ceremony has no historical background as the disputants said, but the arrangements of the ceremony contain with cultural elements.

The explanation above, shows that actually no single agreement implemented by the performers. It is because the performers still keep to implement those arrangements of the ceremony. Therefore, from this discussion, we can conclude that the mediation is unsuccessful and it becomes one of the proofs for the failure of the mediation.

The second proof is prejudice. Although conflict can be solved without violence, but still there is possibility it leaves prejudice. 
According to one of the disputants,${ }^{10}$ the performers' explanation that actually there is no spiritual meaning in the ceremony is just an excuse to solve the problem. But in the fact, they still perform kind of heresy in the procession of arak-arakan and wayangan.

"Maybe the performers can say that 'actually there is no spiritual meaning in the ceremony because it is just cultural ceremony, and we just want to promote our culture. There is no any kind of purpose that can lead to the heresy from this ceremony.' But, that is just the way they try to solve the problem although in the fact they still perform kind of heresy, such as glorifying the siwur and do the ritual of ruwatan in wayang performance."

From his explanation actually shows the disputants do not really believe to the performers although they have organized mediation and achieve some agreements. Therefore, they still keep control the proceedings of the ceremony of Nawu Sendang Saliran annually. They still keep on eye weather the performers still do kind of heresy or no. Therefore, the disputants still have prejudice to the performers of the ceremony of Nawu Sendang Saliran.

In addition, the disputants have prejudice to the performers because some people who come to see the ceremony of Nawn Sendang Saliran regard it as spiritual ceremony. There are some people believe if they come in the ceremony and drink the water from the sendang, will get blessing from the spiritual beings who keep the sendang. It is because they regard the sendang as spiritual landscape. As explained by one of the visitors, he is from Padang (West Sumatra), and come to Jogjakarta because want to see the ceremony of Nawn Sendang Saliran. His reason why he wants to see the ceremony because he wants to get blessing from spiritual beings who keep the sendang. He beliefs that the spiritual beings who keep the sendang is the founder of the sendang itself. ${ }^{11}$

More than that, a lot of people who believe that drinking water from Sendang Saliran can be blessed and cure kind of disease because they believe the water in the sendang has magical power. It is not ruled out if

${ }^{10}$ Suharianto, Interview, 2 March 2015.

11 Supardi, Interview, 25 April 2015.

124 | Sulfia Lilin Nurindah Sari - The Dynamics of Muslims' Perspectives on the Ceremony 
the people who come in the ceremony also hope to get blessing from taking the food in gunungan. For this reason, the disputants oppose the ceremony of Nawn Sendang Saliran although the performers of the ceremony do not give spiritual meaning as well as some of the visitors. It is because Mainstream related to the spiritual being is not recognized in Islam, that's why they say it is not Islamic culture.

Seeing the conflict in the ceremony of Nawn Sendang Saliran, make me raise some question, why religion and culture become the issue that need to be separated in Indonesia? Why culture often become the topic of heresy for religion? And why we consider it as heresy? There are two possibility answers to answer those questions. Those are religious categorization and religious purification.

The first possibility why some local cultures are considered as heresy because some religious people have different categorization to response local cultures. As explained by Hefner, in his article "Where All Abangan Gone? Religionization and the Decline of Non-Standard Islam in Contemporary Indonesia," he explains about religious standardization in Islam. Those standardization is clearly used to differentiate between Islamic religion and culture. A belief which is not qualified in standard of Islam is not considered as part of Islam. Hefner noted,

"In Indonesia since the New Order period, and in some other parts of Southeast Asia as well, for a spiritual tradition to qualify as a 'religion', it must possess several key features: a prophet or founding teacher; a canonical scripture or holy books; standardized rituals and beliefs, knowledge of which is incumbent on all believers; and a clear and consistent differentiation of local custom from universal religion, premised on the idea that the former may not supersede the latter."12

With religious categorization mentioned by Hefner, this has become an idea that actually religious people try to separate Islam and

12 Robert Hefner, "Where have all the Abangan Gone: Religionization and the Decline of Non-standard Islam in Contemporary Indonesia", in Michael Picard and Remy Madinier (eds.), The Politic of Religion in Indonesia: Syncretism, Orthodoxy, and Religious Contention in Java and Bali (New York: Routledge, 2011), 73. 
culture. In other words, culture is fundamentally different from religion. Therefore, we can apply the word standardization used by Hefner to analyze the case of Nawu Sendang Saliran. It is because the disputants also have standardization of culture that acceptable and unacceptable for them. They want to review the arrangements of the ceremony, whether there are practices that contain the presence of heresy. According to the disputants, religion is something that is contained with spiritual beliefs and has deep meaning. Whereas, culture should not have any kind of spiritual meaning. ${ }^{13}$

"Culture is something that does not have any kind of spiritual
meaning, such as Javanese language, Javanese songs, dances, and
instruments. For example, Javanese people who cannot speak
Java, they have lost their identity as Javanese. We should keep our
identity as Javanese. But, something cannot consider as culture if
it contains with spiritual meaning, either the purpose and the
practice."

Many people tried to separate between religion and culture. It is because they think religion and culture are different. Religion is a sacred thing and comes from God, and believed by the public as belief that govern life. While culture is a habit conducted by the society, therefore it becomes a habit believed from generations to generations. But if seen from Durkheim's theory, we cannot say that actually religion and culture are something different. It is because religion is basically a part of the culture itself. Religion is also a habit performed or believed by the public to be a sacred. Therefore, religion and culture are an integral and inseparable combination.

The second possibility is religious purification. Some religious people want to purify their religion. It is explained by the mediator of the conflict in Nawn sendang ceremony, "religion and traditions are always related to a matter of heresy. But it must be distinguished between religious rituals and cultural rituals". ${ }^{14}$ In other world, the mediator's statement indicates that religious rituals and cultural rituals are different.

\footnotetext{
${ }^{13}$ Kaharudin Nur, Interview, 7 March 2015.

${ }^{14}$ Kharis Zubair, Interview, 27 February 2015
}

126 | Sulfia Lilin Nurindah Sari - The Dynamics of Muslims' Perspectives on the Ceremony 
Therefore, people try to purify Islam from the tradition which is contained with spirituality.

With religious purification, they will distinguish something they consider as heresy and endanger their religion. In this case, the disputants also try to reduce the practice of heresy in Islam by creating standardization of local culture that is acceptable and unacceptable. The purpose of those standardization is to reduce Islamic heresy. It is because they want to purify their religious teaching without mixing it with local culture which contain with spiritual purpose. Therefore, they tend to oppose the ceremony of Nawn Sendang Saliran although practically the performers of the ceremony do not perform the ritual that tend to heresy. According to the disputants, it does not rule out the possibility that many people try to animate their local beliefs by mixing Islam and local culture. ${ }^{15}$ Therefore, they still have suspicions to the performers of the ceremony of Nawu Sendang Saliran.

\section{Conclusion}

The standardization of religion in Indonesia makes it clearer that actually many religious people try to separate between culture and religion. Conflict involving religion and culture is a conflict that does need a settlement, so that the existing culture in Indonesia can be preserved well. If every religion considers culture as something heretical and full of suspicion, then there would be no culture that can meet the standards of religion in particular. Credence to the ancestral spirits is an Indonesian heritage trust. Although they have embraced certain religions, but the culture is difficult to be removed from the society. It is caused culture adhered to the society life.

${ }^{15}$ Suharianto, Interview, 02 March 2015. 


\section{Bibliography}

Allerton, Catherine. Introduction: Spiritual Landscapes of Southeast Asia, Anthropological Forum: A Journal of Social Anthropology and Comparative Sociology. 19(3). 2009.

Barash, David P. and Charles P. Webel. Peace and Conflict Studies. California: Sage Publications, 2002.

Beck, Herman. Islamic Purity at Odds with Javanese Identity: The Mubammadiyah and the Celebration of the Gerebeg Maulud Ritual in Yogyakarta. Ed. Pluralism and Identity by jan Platvoet and Karen Van Der Toorn. Leiden, New York, Koln: E. J. Brill, 1995.

Biyanto. Mubammadiyah dan Problema Hubungan Agama-Budaya, ISLAMICA, Vol. 5, No. 1, September. 2010.

Demmers, Jolle. Theories of Violent Conflict: An Introduction. New York: Routledge, 2012.

Comaroff, Jean. "The Politics of Conviction: Faith on the Neo-Liberal Frontier." Social Analysis, 53:1 (2009).

Durkheim, E. The Elementary Forms of the Religious Life. New York: Free Press, 1912.

Eko, P. Aspek Ritual Pementasan Wayang Purwa. Lih. 1990 (019:005) 00050012 Mawas Diri.

Galtung, Johan. 'Violence, Peace and Peace Research', Journal of Peace Research. 1969. 6: 167-191.

. Three Approaches to Peace: Peacekeeping, Peacemaking, and Peace building. Copenhogen: Christian Eljers, 1975.

. Transcend and Transform: An Introduction to Conflict Work. London: Pluto Press, 2004.

Garbin, David. "Marcbing for God in the global society: public space, religion, and diasporic identities in a transnational Church," Culture and Religion 13:4 (December 2012).

128 | Sulfia Lilin Nurindah Sari - The Dynamics of Muslims' Perspectives on the Ceremony 
Geertz, Clifford. The Religion of Java. Chicago and London: The University of Chicago Press, 1960.

Giaccardi, Elisa. Understanding Heritage in a Participatory Culture. Ed. London and New York: Routledge, 2012.

Gort, Jerald D, Henry Jansen, and Hendrik M. Vroom. Religion, Conflict and Reconciliation. Amsterdam-New York: Radopi, 2002.

Harsrinuksmo, Bambang. Ensiklopedi Wayang Indonesia. Jakarta: Sena Wangi, 1999.

Harvey, David. "Neoliberalism as Creative Destruction," Annals AAPSS 610 (2007).

Jacoby, Tim. Understanding Conflict and Violence: Theoretical and Interdisciplinary Approach. New York: Routledge, 2008.

Jayadeva, Uyangoda. Conflict, Conflict Resolution and Peace Building: An Introduction to Theories and Practices. GTZ: Sri Lanka, 2005.

Lorentzen, Lois Ann. "Who is an Indian?: Religion, Globalization and Chiapas," in Hopkins, et al., eds. Religions/Globalization: Theories and Cases (Duke, 2001).

Miall, Hugh, et all. Contemporary Conflict Resolution. UK: Politic Press, 1999.

Muljana, Slamet. Runtubnya Kerajaan Hindu-Jawa dan Timbulnya Negaranegara Islam di Nusantara. Yogyakarta: LKiS, 2005.

Pals, D. L. Introduction Religion: Readings from the Classic Theories. New YorkOxford: Oxford University Press, 2009.

Ramsbotham, Oliver., Tom Woodhouse and Hugh Miall. Contemporary Conflict Resolution: The Prevention, Management and Transformation of Deadly Conflict. $2^{\text {nd }}$ Ed. Cambridge: Polity Press,2006.

Ritchie, Jane., and Jane Lewis. Ed. Qualitative Research Practice: A Guide for Social Science Students and Researchers. London: Sage Publications, 2003. 
Rohimin., Muntholib., Hasbullah., et al. Harmonisasi Agama dan Budaya di Indonesia 2. Jakarta: Balai Penelitian dan Pengembangan Agama Jakarta, 2009.

Roibin. Relasi Agama dan Budaya Masyarakat Kontemporer. Malang: UINMalang Press, 2009.

Sedyawati, Edi. Kebudayaan di Nusantara: Dari Keris, Tor-tor sampai Industri Budaya. Depok: Komunitas Bambu, 2014.

Sen, Amartya. "How to judge Globalism," American Prospect (Winter, 2002).

Sholeh, Khoirul. Wisata Spiritual: Menjelajabi Situs-situs Bersejarah Spiritual di Sekitar Daerah Istimewa Yogyakarta. Yogyakarta: Narasi, 2008.

Sholikhin, Muhammad. Misteri Bulan Suro Perspektif islam Jawa. Yogyakarta: Narasi, 2010. . Ritual dan Tradisi Islam Jawa. Yogyakarta: Narasi, 2010.

Stitt, Allan J. Mediation: A Practical Guide. London: Cavendish Publishing Limited, 2004.

Sugiyono. Metode Penelitian Kuantitatif, Kualitatif dan R\&D, Bandung: Alfabeta, 2011.

Thoyibin, M., Yayah Khisbiyah, dan Abdullah Aly. Sinergi Agama dan Budaya: Dialektika Muhammadiyah dan Seni Lokal. Surakarta: Muhammadiyah University Press, 2003.

Woodward, Mark R. Islam Jawa: Kesalehan Normatif Versus Kebatinan. Trans. Hairus Salim. Yogyakarta: LKis, 1999. 